PIDE Working Papers

2013: 87

\title{
Rent Seeking Opportunities and Economic Growth in Transitional Economies
}

\author{
Nasir Iqbal \\ Pakistan Institute of Development Economics, Islamabad \\ and \\ Vince Daly \\ Department of Economics Kingston University, UK
}

\section{PAKISTAN INSTITUTE OF DEVELOPMENT ECONOMICS} ISLAMABAD 
All rights reserved. No part of this publication may be reproduced, stored in a retrieval system or transmitted in any form or by any means-electronic, mechanical, photocopying, recording or otherwise - without prior permission of the Publications Division, Pakistan Institute of Development Economics, P. O. Box 1091, Islamabad 44000.

\section{(C) Pakistan Institute of Development}

Economics, 2013.

Pakistan Institute of Development Economics

Islamabad, Pakistan

E-mail: publications@ pide.org.pk

Website: http://www.pide.org.pk

Fax: $\quad+92-51-9248065$

Designed, composed, and finished at the Publications Division, PIDE. 


\section{O N T E N T S}

$\begin{array}{lc} & \text { Page } \\ \text { Abstract } & \mathrm{v} \\ \text { 1. Introduction } & 1 \\ \text { 2. Literature Review } & 2 \\ \text { 3. Data and Methodology } & 4 \\ \text { 4. Empirical Results } & 8 \\ \text { 5. Summary and Conclusion } & 13 \\ \text { Appendices } & 14 \\ \text { References } & 16\end{array}$

\section{List of Tables}

Table 1. Validity of the Basic Modelling Framework 9

Table 2. Rent Seeking Opportunities and Economic Growth 10

Table 3. Effects of Corruption, Contingent on Strength of Democracy 


\begin{abstract}
This study empirically explores the growth effects of rent seeking activity (RSA) for a group of 52 developing/transitional countries, using a dynamic panel data approach. The modelling framework is a Mankiw-Romer-Weil (MRW) conditional convergence model augmented by measures of the opportunities for RSA, namely indices for the extent of democracy and corruption control. We find that health is more relevant than educational participation as a measure of human capital development in the MRW model. The overall empirical analysis shows that RSA retards economic growth, in that democratic institutions, which are inimical to RSA, are growth enhancing. We also find that reduction in the extent of corruption is only growth-enhancing if supported by well-developed democratic institutions.
\end{abstract}

JEL Classification: E13, O43, O47

Keywords: Rent-seeking, Economic Growth, Panel Data 


\section{INTRODUCTION}

It is well-known that the neo-classical growth model predicts economic "convergence"- a process in which the passage of time allows poorer countries to catch up with the rich. It is equally common knowledge that such catching up is not yet evidently complete and, for some countries, may seem to have not yet started. One response to this apparent disconnect between the neoclassical growth model and actual experience has been the development of alternative theoretical frameworks, principally the endogenous growth literature [e.g., Romer $(1986,1994)]$. At the same time, it has been shown that the neoclassical framework can retain a better connection with observed reality when augmented by variables that recognise heterogeneity between countries.

In this study we take the position that those variables which most usefully augment the neoclassical framework are not independent of a country's current state of development. We focus in particular upon "middle income" countries, which are typically launched upon a process of economic development but are still in a transitional phase. In these countries we find considerable heterogeneity in opportunities for rent seeking activity (RSA). When we look across these countries we find that the rule of law is not equally effective, property rights are not equally well-defined, democratic rights are not equally extensive. Individuals and organisations that have political or administrative authority will not find that authority equally restricted by checks and balances. Unrestricted authority is an opportunity for rent-seeking behaviour that may redirect resources, violate regulations, and focus effort on wealth re-distribution ("bribery"). The consequences for growth can be negative: resources may not be efficiently allocated, externalities may be ignored, transaction costs may be increased. We do not argue that RSA is absent in more developed economies but believe that there are grounds for expecting them to be "... far more severe in middle and low income countries" [Spinesi (2009)]. Arguments can also be made for some positive consequences of RSA: for example, bribes may facilitate production or trade that would not have happened otherwise, or may serve as signals for growth opportunities; corrupt practices may promote efficiency by allowing private sector agents to circumvent restrictive regulations [Leff (1964); Meon and Weill (2010)].

Acknowledgements: The authors are grateful for comments received from seminar participants at Kingston University, the Deutches Institut für Entwicklungspolitik, and Pakistan Institute of Development Economics, Islamabad. 
In this study we offer an empirical assessment of the overall macroeconomic consequences of institutional frameworks that offer opportunities for RSA. To the best of our knowledge, no recent study has investigated this question empirically for a panel of developing/transitional economies. Our modelling framework is the "MRW" model - the "conditional convergence" model of Mankiw, Romer, and Weil (1992), in which we use health, rather than education, as a human capital indicator and augment the basic model with indicators of the political and regulatory environment, and also augment the dynamics to permit path-dependency. The dynamic nature of this modelling framework leads us to use a GMM approach to estimation and the extent of cross-sectional variation leads us to prefer the "System GMM" estimator of Blundell and Bond (1998).

The rest of this paper is structured as follows. Section 2 summarises the existing literature concerned with the macroeconomic impact of rent-seeking behaviour; section 3 explains the data sources and methodology to be used here; section 4 presents our results and section 5 concludes.

\section{LITERATURE REVIEW}

There are various ways to define rent seeking activity, depending upon the context of analysis. Tullock (1967) defines rent seeking as earning income without being productive. Anderson, at al. (1988) offers the complementary perspective that the pursuit of profits via the use of government coercion is rent seeking. Tollison (1982) observes that RSA can also consist of the allocation of scarce resources so as to create and benefit from economically inefficient transactions. In the same vein, Fischer (2006) asserts that RSA is "usually implying the expenditure of scarce resources, to cause and capture artificiallycreated rents as well as transfers which are not part of society's intended income redistribution" For this present study, RSA is envisaged as any activity through which public power is exercised for private gain; this may involve misuse of public resources or, more generally, any attempted capture and commodification of state, social or commercial authority by politicians, public officials, elites and private interests.

As to when rent seeking might occur, North (1990) argues that the institutional framework is crucial and often provides room for RSA, especially in developing countries. Institutional frameworks that are weak, in the sense of not applying equally and impartially to all individuals - whether by design or in practice, can create opportunities for rent seeking. Examples include the ineffective or partial rule of law, absent or ill-defined property rights and limitations on the extent to which democratic processes exercise authority over key institutions. Such institutional weaknesses provide room for, inter alia, misuse of resources, violations of regulations, restrictions of trade - thus motivating RSA. When it then occurs, rent-seeking may distort the productive 
activities of the economy, imposing social costs. RSA may impede the growth process of an economy in several ways. Firstly, it may merely redistribute wealth; rent seekers do not intend to create new wealth [Brumm (1999)]. Also, in developing countries particularly, rent seekers may hold key positions in the public and private sectors and cause resistance to the adoption of beneficial economic reforms and institutional change [Fischer (2006)]. RSA can further retard economic growth by diverting resources from productive use [Cole and Chawdhry (2002)] and may restrict innovation [Murphy, et al. (1993)] hence obstructing economic development.

North (1990) emphasises that rent-seeking is rarely self-limiting; an institutional framework that allows RSA is likely to encourage expansion of the number of individuals engaged in RSA and construction of additional rent opportunities. He provides various arguments to explain how institutional weaknesses lead to low development in developing countries. First, there may be a conflict between formal and informal rules in countries with poorly developed institutions, with informal rules often overriding the formal laws and regulations. The informal rules can be antagonistic towards free markets, leading to economically inefficient outcomes. Second, enforcement of formal rules can be poor in these economies and lack of enforcement of regulations facilitates RSA. In summary, the incomplete rule of law, non-enforcement of property rights, inadequate policies and the lack of reliable infrastructure constitute a weak institutional framework that may promote RSA.

In developing countries, where the rule of law is weak, where checks and balances are ineffective and public sector management may be poor; most rent seeking is carried out by government officials-examples include legislators, executing and enforcing agencies, members of the armed services, the police force, judges, public sector managers and employees. In these nations, individuals, groups and institutions invest time and wealth to create or modify rules, laws and regulation that favour rent seeking activities and protect already secured rents. Rent seekers influence the legal, political or economic rules by engaging in activities such as lobbying, sponsoring, bribery and exploiting patronage relations - for example, triggering demonstrations, strikes or riots. Bribes may be in cash or in kind. The latter may be simply re-distributive but may sometimes impose a direct risk of economic inefficiency, as for example the promise to organise a job for a relative of the rent-seeking official. Public officials may generate rent by compromising on rule and laws, by threatening the rent distributing agency or its employees, by smuggling, by engaging in capital flight, by forcing inefficient decisions within the private sector [Fischer (2006)].

To our knowledge, not many studies have empirically investigated the impact of RSA on economic growth, and even fewer have been cross-national in scope. ${ }^{1}$ Laband and Sophocleus (1988), using time series data over the period

${ }^{1}$ See De Rosal (2011) for a comprehensive review of literature on rent seeking. 
1947-1983, use the number of registered lawyers as a measure of RSA and find a negative relationship with growth of per capita income in the USA. Brumm (1999) analyses the impact of RSA, using several proxies, including an index of lobbying-law restrictions, state government employment and legal services, and finds a negative relationship with economic growth in US states. Cole and Chawdhry (2002) examine the impact of RSA on economic growth of US states over the period 1980-1990 by employing a panel data vector autoregressive (VAR) model. This study uses public sector employment and the number of registered lobbyists as proxies for RSA and concludes that RSA has a negative impact on economic growth. This previous research reveals the difficulty of constructing direct measures of RSA; the present study focusses therefore on obtaining measures of the ease with which RSA may be undertaken, in particular the extent to which institutional frameworks accommodate RSA. Laband and Sophocleus (1988) and Brumm (1999) do not tackle the problem of mutual causation between RSA and economic growth as pointed to in the literature [e.g., Murphy, et al. (1991)]. Cole and Chawdhry (2002) accommodate this to some extent by using a VAR framework. The present study employs a single equation model but applies an estimator that requires only weak exogeneity in the regressors. We do not discount the possibility that a country's growth experience can, over time, influence the evolution of its institutional environment but we do assume that current shocks to growth do not have an immediate impact, and we then establish absence of simultaneity by confirming, via autocorrelation tests, that current shocks are independent of preceding shocks. Our single equation approach is then a valid vehicle for investigating the structural dependence of growth upon the selected institutional variables.

It should be acknowledged that here are theoretical reasons and some empirical support to suggest that RSA can sometimes be supportive of growth. For example, Mork (1993) and Gray and Lowery (1996) show that rent seeking, as proxied by lobbying activities, has a strong positive impact on economic growth. Our interest in this study is to discover whether or not, on balance across a span of countries and of years, the macroeconomic consequences of RSA have been seen to be predominantly negative.

\section{DATA AND METHODOLOGY}

To analyse the growth effects of rent seeking activities, we employ a panel data set of 52 developing/transitional economies drawn from the World Bank's "middle income" group. ${ }^{2}$ Our data series for the core MRW model

\footnotetext{
${ }^{2}$ The World Bank divides countries in three groups according to 2011 GNI per capita. The groups are: "low income" (\$1,025 or less); "middle income" $(\$ 1,026-\$ 12,475)$; and "high income" $(\$ 12,476$ or more). We began data collection for all 108 countries in the middle income group and found 52 countries for which all data are available. Appendix table 1 lists the countries included in the estimation sample.
} 
span1986-2010; for the augmented model we have data for the period 19962010. We focus on countries in the middle-income group since we expect that the MRW model to be applicable, more so than for the low income group, and that there will be a sufficient cross-country range of variation in the variables of interest. Although our data selection is focused, it is not restrictive to the point of irrelevance, in the sense that the middle income group constitutes around one half of the countries in the World Bank's databank.

Directly observed measures of RSA are rare. The existing literature uses various proxies to measure RSA, including government size [Grossman (1988); Durden (1990)], number of lawyers [Laband and Sophcleus (1988); Murphy, et al., (1991)], lobbying [Rama (1993); Mork (1993); Brumm (1999); Cole and Chawdhry (2002)], public sector employment [Gelb, et al. (1991); Brumm (1999); Cole and Chawdhry (2002); Park, et al. (2005)], bureaucratic structure [Spinesi (2009)] and corruption [Svensson (2000); Mohtdi and Roe (2003)]. Few of these proxies are applicable in a multi-country study and we focus instead on obtaining measures of the ease with which RSA may be undertaken, in particular the extent to which institutional frameworks accommodate RSA.

As detailed above, opportunities for RSA occur when individuals or organisations can establish authority over aspects of the economic sphere. Whilst we are not able to directly observe RSA, we do have measures of two institutional features that can arguably limit the extent of such authority. The first such feature is widely distributed political rights, as in an effective democracy. Democracy does not remove positions of authority but makes them contestable so that office holders risk losing their rent-generating authority if they seek to harvest those rents and retain them; strong democracy therefore tends to make RSA unprofitable. Data on the extent of democracy is available from POLITY IV. ${ }^{3}$ This index emphasises the institutional characteristics of democracy, as measured by competitiveness of political participation, competitiveness of executive recruitment, openness of executive recruitment and constraints on the chief executive.

The second important institutional feature to limit RSA is completeness and effectiveness of the regulatory framework, whereby the rule of law becomes a sufficiently strong countervailing authority as to attach preventative penalties to RSA, again making such behaviour unprofitable. We use measures that capture the extent to which perceived RSA is minimised, i.e. control of corruption and freedom from corruption. Data on control of corruption are taken from Worldwide Governance Indicators (WGI) published by the World Bank. This index measures the perceived extent to which public power is exercised for private gain, including petty and grand forms of corruption, as well as "capture" of the state by elites and private interest. Data on freedom from corruption are

${ }^{3}$ See appendix Table 2 for detailed definition of variables and their sources. 
taken from The Heritage Foundation. This index measures the perceived level of corruption as it affects a country's economic freedom by introducing insecurity and uncertainty into the economic relationships. Data on core variables for the MRW model: GDP, physical capital and human capital, are taken from the World Development Indicators (WDI) published by the World Bank.

The introduction and literature survey have highlighted the potential for linkages between RSA and economic growth, noting that arguments have been advanced to explain why RSA may both hinder and also support economic development. To empirically assess the overall consequences of RSA for economic growth, we extend the basic MRW model. Following Cole and Chawdhry (2002), we incorporate measures of opportunities for rent-seeking into the MRW model. Our modelling framework is:

$$
\Delta Y_{i t}=\alpha+\beta Y_{i, t-1}+\gamma \Delta Y_{i, t-1}+\delta_{P C} P C_{i t}+\delta_{H C} H C_{i t}+\rho R_{i t}+u_{i}+\varepsilon_{i t} .
$$

in which $i$ indexes the countries and $t$ denotes time. The variables involved are:

$Y$ the logarithm of real gross domestic product (GDP) per capita,

$P C$ a measure of physical capital investment

$H C$ a measure of human capital investment

$R \quad$ a measure of opportunities for rent-seeking

$u$ an unobserved time-invariant fixed effect

$\varepsilon \quad$ an unobserved random disturbance

The basis of this framework is the "unconditional convergence" model of Barro and Salai-Martin (1992, 2004 Ch.2): $\left(Y_{i t}-Y_{i 0}\right)=\alpha+\beta Y_{i 0}$, which is a log-linear approximation around steady state for a neoclassical growth model with Cobb-Douglas technology. For parameter constancy across the time dimension of a panel data set, lagged levels of per capita GDP are taken with a fixed lag: $Y_{i, t-1}$, rather than from a fixed "initial" year: $Y_{i 0}$. Following MRW, the unconditional convergence model is augmented by measures of investment in physical and human capital, to provide a "conditional convergence" model. The inclusion of a lagged dependent variable allows for path dependency in the influence of these and other driving variables. As is generally the case in such a modelling framework, participation in education is used as an indicator of investment in human capital. We follow Knowles and Owen (1995) and Sachs and Warner (1997) by also including a measure of population health since development of the productive capacity of the workforce may be achieved by improving healthiness as well as the level of education. The modelling framework is completed by permitting cross-sectional heterogeneity in the level and rate of change of $\mathrm{X}$-inefficiency in production; this heterogeneity is partially unobserved: $u_{i}$, and partially a consequence of cross-sectional differences in the extent of rent-seeking behaviour. 
As is well known, the presence amongst the regressors of lagged endogenous variables, $Y_{i, t-1}$ and $\Delta Y_{i, t-1}$, renders the traditional "fixed effects" and "random effects" panel estimators inconsistent. There are two main approaches to dealing with this endogeneity problem. One approach ("LSDVC") corrects the traditional fixed effects ("LSDV") estimator by an estimate of the endogeneity bias [Kiviet (1995)]. The other approach is to abandon least squares estimation in favour of instrumental variable methods, since the use of exogenous instruments should be expected to produce consistent estimators.

Anderson and Hsaio (1982) (AH) suggest transforming to first differences to eliminate the time-invariant fixed effects and applying IV estimation with lagged differences or levels as instruments. Further research [Kiviet (1995)] has suggested that lagged levels are a superior choice for data that has finite time dimension.

The AH estimator is an example of simple IV estimation, in which there is one instrument for each endogenous variable. A natural generalisation of this estimator is GMM in which the number of instruments is permitted to exceed the number of endogenous variables. A popular example of GMM is Arellano and Bond (1991) (AB) which suggests using all valid lags of all regressors as instruments. The efficiency of GMM estimation is generally increasing in the number of valid and effective moment conditions - valid by virtue of an instrument being (at least weakly) exogenous and effective by virtue of it having better than weak correlation with the endogenous variables. In principle, therefore, the $\mathrm{AB}$ estimator should be superior to the $\mathrm{AH}$ estimator. This superiority might, however, be absent or minimal if the panel has a short time dimension and thus limited opportunity for applying the $\mathrm{AB}$ instrumentation strategy. Additionally, and relevant to the estimation of growth models, if a macroeconomic series, such as per capita GDP, is AR1 with a close-to-unit root then its first differences have only weak correlation with its lagged levels. Bond, et al. (2001) show that in this case, GMM applied to a first-differenced levels model instrumented with lagged levels-as in $\mathrm{AB}$, may suffer a severe "weak instruments" problem, and thus poor precision in finite samples. One solution to this problem is due to Arellano and Bover (1995) and Blundell and Bond (1998), who show that an assumption of stationarity in the time dimension justifies additional zero-moment restrictions that can be applied to a model in levels, instrumented with lagged differences. These additional moment restrictions can be combined with those in AB to provide a "system-GMM" estimator in which GMM is applied to a system of two equations: an equation in differences instrumented by lagged levels, and an equation in levels instrumented by lagged differences.

Since our own modelling framework is expressed initially in differences, the risk of weak instruments by virtue of near-unit root behaviour in the dependent series is much reduced. However, Bond, et al. (2001) note that weak 
instrumentation for the $\mathrm{AB}$ estimator can also arise when the persistent unobserved cross-sectional heterogeneity $\left(u_{i}\right)$ has significantly higher variance than the transient disturbances $\left(\varepsilon_{i t}\right)$. Because of the substantial heterogeneity in our cross-section of countries we therefore employ the system-GMM estimator. ${ }^{4}$

For lagged endogenous variables and weakly exogenous variables to be valid as instruments, it is necessary that the transient disturbances in the base model, $\varepsilon_{i t}$, are free of autocorrelation [Blundell and Bond (1998), p. 118]. This would imply that the disturbances in the differenced model have significant first-order correlation and insignificant second-order autocorrelation. For this purpose, the Arellano-Bond tests for first-order and second-order serial correlation in the first-differenced residuals are used [see Arellano and Bond (1991)]. Because the first difference of independently and identically distributed idiosyncratic error will be serially correlated, rejecting the null hypothesis of no serial correlation in the first-differenced error at order one does not imply that model is misspecified. Rejecting the null hypothesis at higher orders, however, implies that the moment conditions are not valid.

\section{EMPIRICAL RESULTS}

We begin by checking the validity of the MRW conditional convergence model for the time period and range of countries in our data set. At the same time, we explore whether there is empirical support here for the proposition that health is an important dimension of human capital, alongside education. Results of diagnostic tests (AR1 and AR2 tests) are consistent with the requirements for instrument validity. In principle, instrument validity might also be directly tested by, say, a Sargan test but the behaviour of this test statistic is only well known when disturbances can be assumed homoscedastic, which is not the case here.

Table 1 indicates that the data support the basic MRW model, whether the selected dimension for human capital formation (HC) is education - measured here by participation rates, or healthiness-measured by longevity. The negative coefficients on the lagged levels of per capita GDP, together with the small positive coefficients on the lagged growth rates, support the neoclassical hypothesis of convergence to a long-run steady state. This steady state is country-specific by virtue of the cross-sectional heterogeneity in fixed effects and capital formation, and the speed of convergence to it is path-dependent. We find that health and education are not jointly significant, with healthiness of the working population - in model (3), dominating education level as a contributor to growth. This finding echoes in a panel context the results obtained by Knowles and Owen (1995), using the MRW cross-section data. In a more recent study, Hartwig (2010) finds no empirical support for a link between health and growth in a sample of OECD countries. We rationalise these conflicting findings

${ }^{4}$ Estimation is performed in STATA v11, using 'xtdpdsys' with robust standard errors. 
Table 1

Validity of the Basic Modelling Framework

\begin{tabular}{lccc}
\hline Variables & $(1)$ & $(2)$ & $(3)$ \\
\hline GDP/PC growth (-1) & 0.249 & 0.241 & 0.245 \\
& $(0.06)^{* * *}$ & $(0.06)^{* * *}$ & $(0.06)^{* * *}$ \\
GDP/PC(-1) & -0.002 & -0.002 & -0.003 \\
& $(0.00)^{* * *}$ & $(0.00)^{* * *}$ & $(0.00)^{* * *}$ \\
Physical Capital & 0.145 & 0.128 & 0.134 \\
& $(0.06)^{* *}$ & $(0.06)^{* *}$ & $(0.06)^{* *}$ \\
HC (education) & 21.389 & & 9.869 \\
& $(6.21)^{* * *}$ & & $(9.24)$ \\
HC (health) & & 32.519 & 24.974 \\
& & $(8.34)^{* * *}$ & $(11.49)^{* *}$ \\
Constant & -7.842 & -18.774 & -18.215 \\
& $(2.69)^{* * *}$ & $(5.69)^{* * *}$ & $(5.57)^{* * *}$ \\
Observations & 1,248 & 1,248 & 1,248 \\
Number of Countries & 52 & 52 & 52 \\
chi ${ }^{2}$ p-value & 0.000 & 0.000 & 0.000 \\
AR1 p-value & 0.0000 & 0.0000 & 0.0000 \\
AR2 p-value & 0.8330 & 0.8386 & 0.8192 \\
\hline
\end{tabular}

Robust standard errors in parentheses.

$* * * \mathrm{p}<0.01, * * \mathrm{p}<0.05, * \mathrm{p}<0.1$

by suggesting that the relative importance of education and health as factors influencing the current rate of growth of per capita GDP is dependent in part upon the sectoral profile of economic activity, with high value-added production having the greater need for an educated work-force and being less prevalent in developing economies. The selection of countries studied here are seemingly at a stage of development where health is a more significant contributor to growth than is education. In what follows we therefore use health as the preferred measure of human capital. Our use of panel data, rather than cross-section, means that we can accept the possibility of bi-directional causation between growth and driving regressors, such as health and education, needing only to assume a causal ordering with the current rate of growth not causal for the current regressors.

In Table 2 we explore the impact upon growth of the variables that characterise the environment for RSA: strength of democracy, control of corruption and freedom from corruption ${ }^{5}$. Models 1, 2, 3 augment the basic model with each of these institutional variables individually. Strength of democracy exhibits the strongest statistical significance and is retained in models 4,5 , where it is paired in turn with the two corruption indices.

${ }^{5}$ The simple correlations between these indices are not of a size to indicate that multicollinearity may be problematic. 
Table 2

Rent Seeking Opportunities and Economic Growth

\begin{tabular}{|c|c|c|c|c|c|}
\hline Variables & (1) & (2) & (3) & (4) & (5) \\
\hline \multirow[t]{2}{*}{ GDP/PC growth (-1) } & 0.238 & 0.144 & 0.148 & 0.147 & 0.152 \\
\hline & $(0.06)^{* * *}$ & $(0.07)^{* *}$ & $(0.07)^{* *}$ & $(0.07)^{* *}$ & $(0.07)^{* *}$ \\
\hline \multirow[t]{2}{*}{ GDP/PC(-1) } & -0.002 & -0.002 & -0.002 & -0.002 & -0.002 \\
\hline & $(0.00)^{* * *}$ & $(0.00)^{* * *}$ & $(0.00)^{* * *}$ & $(0.00)^{* * *}$ & $(0.00)^{* * *}$ \\
\hline \multirow[t]{2}{*}{ Physical Capital } & 0.134 & 0.116 & 0.126 & 0.118 & 0.118 \\
\hline & $(0.06)^{* *}$ & $(0.07)^{*}$ & $(0.07)^{*}$ & $(0.07)^{*}$ & $(0.07)^{*}$ \\
\hline \multirow[t]{2}{*}{ HC (health) } & 27.421 & 36.761 & 36.124 & 32.085 & 31.072 \\
\hline & $(8.19)^{* * *}$ & $(8.47)^{* * * *}$ & $(8.18)^{* * *}$ & $(8.93)^{* * *}$ & $(8.63)^{* * *}$ \\
\hline \multirow[t]{2}{*}{ Democracy } & 0.431 & & & 0.332 & 0.362 \\
\hline & $(0.16)^{* * *}$ & & & $(0.17)^{* *}$ & $(0.17)^{* *}$ \\
\hline \multirow[t]{2}{*}{ Control of corruption } & & 0.067 & & 0.065 & \\
\hline & & $(0.05)$ & & $(0.06)$ & \\
\hline \multirow{2}{*}{$\begin{array}{l}\text { Freedom from } \\
\text { corruption }\end{array}$} & & & 0.444 & & 0.484 \\
\hline & & & $(0.25)^{*}$ & & $(0.26)^{*}$ \\
\hline \multirow[t]{2}{*}{ Constant } & -17.417 & -22.533 & -23.262 & -20.892 & -21.646 \\
\hline & $(5.34)^{* * *}$ & $(6.52)^{* * *}$ & $(6.40)^{* * *}$ & $(6.51)^{* * *}$ & $(6.42) * * *$ \\
\hline Observations & 1,248 & 780 & 780 & 780 & 780 \\
\hline Number of Countries & 52 & 52 & 52 & 52 & 52 \\
\hline chi $^{2}$ p-value & 0.000 & 0.000 & 0.000 & 0.000 & 0.000 \\
\hline AR1 p-value & 0.0000 & 0.0000 & 0.0000 & 0.0000 & 0.0000 \\
\hline AR2 p-value & 0.8681 & 0.2742 & 0.3098 & 0.3061 & 0.3565 \\
\hline
\end{tabular}

Robust standard errors in parentheses.

$* * * \mathrm{p}<0.01, * * \mathrm{p}<0.05, * \mathrm{p}<0.1$.

Table 2 suggests that strength of democracy exerts a positive and significant influence upon growth. This suggestion is not new within the literature but empirical evidence has been mixed; Narayan, et al. (2011) survey the conflicting conclusions within the literature. In their own "Granger Causality" study of countries within sub-Saharan Africa, they find a positive influence of democracy upon growth for some, but not all, individual countries. More recently, Peev and Mueller (2012) conclude that, for post-communist countries, democracy has brought both growth enhancing and growth retarding reforms. A recent study of the Portuguese experience by Corujo and Simoes (2012) suggests that strengthening democracy may have a negative short-run 
impact upon growth despite a positive long-run influence. Our own approach differs from these recent studies by explicitly expressing the neoclassical growth theory framework within a dynamic panel setting and employing an appropriate estimator. Calderon and Chong (2007), employing a Granger causality approach for an empirical investigation of the link between democracy and rent seeking in Uruguay, reach conclusions compatible with our own. They find that long periods of democracy are favourable to a decrease in rent seeking. Various reasons may be advanced for this positive influence of democracy on economic growth. With weak democratic institutions, politicians and public officials have fewer checks on their power, making it easier for them to engage in rent seeking. Democracy also allows citizens periodically to evict politicians who are thought to have damaged the economy [Drury, et al. (2006)]. By making political authority contestable, democracy can also facilitate the competing away of monopoly rents. Mohtadi and Roe (2003) offer a formal model to support this argument: under weak democracy, agents who possess a rent-seeking opportunity act as monopolistic competitors, earning rents; democracy reduces the opportunity to monopolise political authority, exposing rent-seekers to competition.

Table 2 does not find a strong connection between growth and the indicators of the perceived control of or freedom from corruption. This is an unexpected contrast with the results for the influence of democracy on growth. We therefore proceed by investigating further the influence of corruption, with the influence of democracy treated as an established and maintained hypothesis. We express this maintained hypothesis by transforming the observed strength of democracy to a binary indicator of "weakly democratic" vs. "strongly democratic" environments. The range of values for the democracy index is from 0 to 10; our criterion for "strong democracy" is that a country's average score for this variable during 1986-2010 exceeds 5 . We split the selection of countries into a "weak" group and a "strong" group, according to this binary indicator and fit an augmented MRW model to each group separately.

In Table 3 we find that, for the "weak democracy" countries, the effect of corruption on growth is statistically insignificant for both indices, and the sign of the effect is inconsistent between the two indices. In contrast, in the "strong democracy" group, a reduction in corruption is growthenhancing for both indices. We can also see that the basic modelling framework performs differently in the two groups. The convergence effect is present in both groups but the smoothing effect of path-dependency is not significant in the "weak democracy" group. In this group, investment in physical capital is not statistically significant; the overall impression given by the estimated model is that of a group of countries whose growth experience is relatively uncertain and fragile, when compared with the countries in the "strong democracy" group. 
Table 3

Effects of Corruption, Contingent on Strength of Democracy

\begin{tabular}{lccccc}
\hline & \multicolumn{2}{c}{ Weak Democracy } & & \multicolumn{2}{c}{ Strong Democracy } \\
\cline { 2 - 3 } \cline { 5 - 6 } Variables & $(1)$ & $(2)$ & & $(3)$ & $(4)$ \\
\hline GDP/PC growth (-1) & 0.201 & 0.200 & 0.127 & 0.120 \\
& $(0.15)$ & $(0.15)$ & $(0.05)^{* *}$ & $(0.06)^{* *}$ \\
GDP/PC(-1) & -0.001 & -0.001 & -0.001 & -0.001 \\
& $(0.00)^{* * *}$ & $(0.00)^{* *}$ & $(0.00)^{* *}$ & $(0.00)^{* * *}$ \\
Physical Capital & -0.018 & -0.027 & 0.189 & 0.195 \\
& $(0.08)$ & $(0.08)$ & $(0.06)^{* * *}$ & $(0.07)^{* * *}$ \\
HC (Health) & 23.941 & 23.454 & 28.144 & 22.832 \\
& $(9.84)^{* *}$ & $(9.71)^{* *}$ & $(14.39)^{*}$ & $(13.33)^{*}$ \\
Control of corruption & 0.026 & & 0.070 & \\
& $(0.08)$ & & $(0.04)^{*}$ & \\
Freedom from corruption & & -0.236 & & 0.555 \\
& & $(0.31)$ & & $(0.33)^{*}$ \\
Constant & -11.603 & -10.301 & -20.809 & -15.041 \\
& $(7.60)$ & $(7.61)$ & $(10.94)^{*}$ & $(12.69)$ \\
Observations & 330 & 330 & 450 & 450 \\
Number of Countries & 22 & 22 & 30 & 30 \\
chi ${ }^{2}$ p-value & 0.000 & 0.000 & 0.000 & 0.000 \\
AR1 Test & 0.0054 & 0.0051 & 0.0002 & 0.0002 \\
AR2 Test & 0.3691 & 0.3597 & 0.4393 & 0.2864 \\
\hline
\end{tabular}

Robust standard errors in parentheses.

$* * * \mathrm{p}<0.01, * * \mathrm{p}<0.05, * \mathrm{p}<0.1$.

We conclude that a strongly democratic political environment tends to make anti-corruption measures growth enhancing. This finding is in line with previous studies [Drury, et al. (2006); Mendex and Sepulveda (2006)]. The strength of democracy appears not only to directly reduce opportunities for RSA but also to render effective the regulatory and legal institutions intended to limit the opportunity for corruption. In related work, ${ }^{6}$ Aidt, et al. (2008) also discover that control of corruption has a positive impact on economic growth only in countries with high quality institutions and does not influence growth in countries with low quality of institutions.

Research into the influence of RSA upon the pace of economic development benefits, in principle, from direct observation of the intensity of RSA. In the absence of such information for our panel of transition economies, we conclude that the empirical evidence nevertheless rejects any claim that RSA is predominantly supportive of economic development since we have been able to show that institutional barriers to RSA are generally growth enhancing.

${ }^{6}$ Their study differs in detail from this, in that they use a threshold modelling approach and employ individual observable aspects of democracy as instruments for cross-sectional estimation of the impact of corruption on growth. 


\section{SUMMARY AND CONCLUSION}

Using a panel of 52 developing/transitional countries, this study has offered an empirical assessment of the overall macroeconomic consequences of institutional frameworks that restrict opportunities for RSA. The framework for empirical analysis is the MRW conditional convergence model, with pathdependence, and augmented by measures of the opportunities for RSA - namely indices for the extent of democracy and the perceived extent of corruption. The dynamic nature of this modelling framework led us to use a GMM approach to estimation and the extent of cross-sectional variation led us to prefer the "System GMM" estimator.

Confirming a suggestion found elsewhere in the literature, we find that for this selection of countries health is more relevant than educational participation as a measure of human capital development in the MRW model. As to our main research question, the overall empirical analysis has shown that RSA retards economic growth, in that democratic institutions, which are inimical to RSA, are growth enhancing. We also find that reduction in the perceived extent of corrupt practices can be growth-enhancing, but only if supported by well-developed democratic institutions. ${ }^{7}$

When our sample is split into "strong democracy" and "weak democracy" panels, we find further interesting differences between the fit of the augmented MRW model. In the "weakly democratic" countries we find an absence of path dependence; the growth experience thus appears fragile and uncertain in the sense that random disturbances have relatively high persistence, compared to the countries with an institutional framework that is more supportive of growth. In this RSA-prone group of countries we also find an insignificant coefficient for physical capital investment; we conjecture that a relatively high incidence of RSA in countries where institutional frameworks do not constrain such behaviour may make fixed capital formation an unreliable contributor to growth since (i) corruption of commercial and public sector decision making processes may lead to relatively unproductive investment decisions and (ii) data series for fixed capital formation do not recognise the possibly high incidence of "leakage", in which funds have been corruptly diverted away from their declared purpose but are still recorded as representing fixed capital formation.

The main policy implication of this study is that governance institutions which are not overtly "economic" in their focus may nevertheless be integral to economic development. We have found that democracy in and of itself is associated with more sustainable economic development for transition economies and additionally, within the more democratic countries, a reduced incidence of (perceived) corruption is associated with faster growth.

\footnotetext{
${ }^{7}$ This conclusion might be seen as reversing the tentative priority assigned to "bureaucratic efficiency" over "political stability" by Mauro (1995, p705) on the basis of cross-sectional data for a more diverse group of countries.
} 


\section{APPENDIX}

Appendix Table 1

List of Countries

\begin{tabular}{|c|c|c|c|}
\hline No. & $\begin{array}{l}\text { Countries with Strong } \\
\text { Democracy }\end{array}$ & No. & $\begin{array}{l}\text { Countries with Weak } \\
\text { Democracy }\end{array}$ \\
\hline 1 & Albania & 1 & Algeria \\
\hline 2 & Argentina & 2 & Angola \\
\hline 3 & Bolivia & 3 & Cameroon \\
\hline 4 & Botswana & 4 & China \\
\hline 5 & Brazil & 5 & Cote d'Ivoire \\
\hline 6 & Bulgaria & 6 & Cuba \\
\hline 7 & Chile & 7 & Egypt \\
\hline 8 & Colombia & 8 & Gabon \\
\hline 9 & Costa Rica & 9 & Ghana \\
\hline 10 & Dominican Republic & 10 & Guyana \\
\hline 11 & Ecuador & 11 & Indonesia \\
\hline 12 & El Salvador & 12 & Iran \\
\hline 13 & Guatemala & 13 & Jordan \\
\hline 14 & Honduras & 14 & Malaysia \\
\hline 15 & India & 15 & Morocco \\
\hline 16 & Jamaica & 16 & Pakistan \\
\hline 17 & Mexico & 17 & Papua New Guinea \\
\hline 18 & Mongolia & 18 & Senegal \\
\hline 19 & Namibia & 19 & Sudan \\
\hline 20 & Nicaragua & 20 & Syria \\
\hline 21 & Panama & 21 & Tunisia \\
\hline 22 & Paraguay & 22 & Zambia \\
\hline 23 & Peru & & \\
\hline 24 & Philippines & & \\
\hline 25 & Romania & & \\
\hline 26 & South Africa & & \\
\hline 27 & Sri Lanka & & \\
\hline 28 & Thailand & & \\
\hline 29 & Turkey & & \\
\hline 30 & Uruguay & & \\
\hline
\end{tabular}


Appendix Table 2

Data Definitions and Sources

\begin{tabular}{|c|c|c|}
\hline Variables & Definition & Source \\
\hline $\begin{array}{l}\text { Control of } \\
\text { corruption }\end{array}$ & $\begin{array}{l}\text { This index measures the extent to which public power is } \\
\text { exercised for private gain, including petty and grand } \\
\text { forms of corruption, as well as "capture" of the state by } \\
\text { elites and private interest. Index ranges from }-2.5 \text { to } \\
+2.5 \text {. Higher values represent better control of } \\
\text { corruption and vice versa. The index is rescaled from } 0 \\
\text { (for very poor control) to } 10 \text { (very high control). }\end{array}$ & $\begin{array}{l}\text { Worldwide } \\
\text { Governance } \\
\text { Indicators } \\
\text { (WGI) }\end{array}$ \\
\hline $\begin{array}{l}\text { Freedom } \\
\text { from } \\
\text { corruption }\end{array}$ & $\begin{array}{l}\text { This index is one of the components of the Index of } \\
\text { Economic Freedom. Corruption, the misuse of public } \\
\text { power for private benefits, is perceived to exist among } \\
\text { the public officials and politicians. This survey-based } \\
\text { index measures the perceived level of corruption as it } \\
\text { affects a country's economic freedom by introducing } \\
\text { insecurity and uncertainty into the economic } \\
\text { relationships. The higher the level of corruption, the } \\
\text { lower the level of overall economic freedom and the } \\
\text { lower a country's score. The value ranges from } 0 \text { to } \\
\text { 100. The index is rescaled here from } 0 \text { (very corrupt } \\
\text { government) to } 10 \text { (free from corruption). }\end{array}$ & $\begin{array}{l}\text { The Heritage } \\
\text { Foundation }\end{array}$ \\
\hline Democracy & $\begin{array}{l}\text { This index emphasises the institutional characteristics of } \\
\text { democracy and is measured by competitiveness of } \\
\text { political participation, competitiveness of executive } \\
\text { recruitment, openness of executive recruitment and } \\
\text { constraints on the chief executive. The variable ranges } \\
\text { from zero to ten, where higher values represent a higher } \\
\text { degree of institutionalised democracy. }\end{array}$ & POLITY IV \\
\hline $\begin{array}{l}\text { Human } \\
\text { capital }\end{array}$ & $\begin{array}{l}\text { For this we use two indicators (i) the education index is } \\
\text { measured by the adult literacy rate and the combined } \\
\text { primary, secondary and tertiary gross enrolment ratio, } \\
\text { and (ii) the health index is measured by using life } \\
\text { expectancy at birth that indicates the number of years a } \\
\text { newborn infant would live it prevailing patterns of } \\
\text { mortality at the time of its birth were to stay the same } \\
\text { throughout its life. }\end{array}$ & $\begin{array}{l}\text { WDI and } \\
\text { UNDP }\end{array}$ \\
\hline $\begin{array}{l}\text { Physical } \\
\text { Capital }\end{array}$ & $\begin{array}{l}\text { Investment is used as proxy for physical capital that is } \\
\text { measured as gross fixed capital formation as percent of } \\
\text { GDP. }\end{array}$ & WDI \\
\hline $\begin{array}{l}\text { GDP per } \\
\text { capita }\end{array}$ & $\begin{array}{l}\text { GDP per capita is gross domestic product divided by } \\
\text { midyear population. Data are in constant U.S. dollars }\end{array}$ & WDI \\
\hline $\begin{array}{l}\text { GDP per } \\
\text { capita growth }\end{array}$ & $\begin{array}{l}\text { Annual percentage growth rate of GDP per capita based } \\
\text { on constant local currency. }\end{array}$ & WDI \\
\hline
\end{tabular}




\section{REFERENCES}

Aidt, T., J. Dutta, and V. Sena (2008) Governance Regimes, Corruption and Growth: Theory and Evidence. Journal of Comparative Economics 36:2, 195-220.

Aixala, J. and G. Fabro (2009) Economic Freedom, Civil Liberties, Political Rights and Economic Growth: A Causality Analysis. Spanish Economic Review 11:3, 165-178.

Anderson, G. M., C. K. Rowley, and R. D. Tollison (1988) Rent-Seeking and the Restriction of Human Exchange. Journal of Legal Studies 27, 83-100.

Arellano, M. and S. Bond (1991) Some Tests of Specification for Panel Data: Monte Carlo Evidence and an Application to Employment Equations. Review of Economic Studies 58:2, 277-97.

Arellano, M. and O. Bover (1995) Another Look at the Instrumental Variable Estimation of Error-components Models. Journal of Econometrics 68:1, 2951.

Barro, R. and X. Sala-i-Martin (1992) Convergence. Journal of Political Economy 100:2, 223-51.

Barro, R. and X. Sala-i-Martin (2004) Economic Growth, 2nd ed. Cambridge, Mass, London: MIT.

Barro, R. J. (1991) Economic Growth in a Cross Section of Countries. The Quarterly Journal of Economics 106:2, 407-443.

Blundell, R. and S. Bond (1998) Initial Conditions and Moment Restrictions in Dynamic Panel Data Models. Journal of Econometrics 87:1, 115-143.

Bond, S., C. Bowsher, and F. Windmeijer (2001) Criterion-based Inference for GMM in Autoregressive Panel Data Models. Economics Letters 73:3, 397388.

Bond, S., A. Hoeffler, and J. Temple (2001) GMM Estimation of Empirical Growth Models. London C.E.P.R. (CEPR Discussion Papers: 3048).

Brumm, H. J. (1999) Rent Seeking and Economic Growth: Evidence from the States. Cato Journal 19:1, (Spring/Summer) 7-16.

Brumm, H. J. (1999) Rent Seeking and Economic Growth: Evidence from the States. Cato Journal 19:1, 7-16.

Caselli, F., G. Esquivel, and F. Lefort (1996) Reopening the Convergence Debate: A New Look at Cross-country Growth Empirics. The Journal of Economic Growth 1:3, 363-389.

Chakraborty, S. and E. Dabla-Norris (2006) Rent Seeking. IMF Staff Papers $53: 1,2$.

Cheikbossian, G. (2003) Property Rights, Rent Seeking and Aggregate Outcomes in Transition Economies. Economic System 27:3, 271-288.

Cole, I. M. and M. A. Chawdhry (2002) Rent Seeking and Economic Growth: Evidence from A Panel of U.S. States. Cato Journal 22:2, 211-228.

Corujo, S. A. and M. N. Simoes (2012) Democracy and Growth: Evidence for Portugal (1960-2001). Transition Studies Review 18:3, 512-528. 
Croix, D. and C. Delavallade (2009) Why Corrupt Governments May Receive More Foreign Aid. IRES. (Discussion Papers).

Calderón, C. and A. Chong (2007) Rent Seeking and Democracy: Empirical Evidence for Uruguay. Economic Inquiry 45:3, 592-601.

Del Rosal, I. (2011) The Empirical Measurement of Rent-Seeking Costs. Journal of Economic Surveys 25:2, 298-325.

Drury, A. C., J. Krieckhaus, and M. Lusztig (2006) Corruption, Democracy, and Economic Growth. International Political Science Review 27:2, 121-136.

Durden, G. (1990) The Effect of Rent Seeking on Family Income Levels: Some Suggestive Empirical Evidence. Public Choice 67, 285-291.

Fischer, P. V. (2006) Rent-Seeking, Institutions and Reforms In Africa: Theory and Empirical Evidence for Tanzania. USA: Springer Science and Business Media Press.

Gelb, A. J., B. Knight, and R. H. Sabot (1991) Public Sector Employment, Rent Seeking and Economic Growth. The Economic Journal 101:408, 1186-1199.

Gray, V. and D. Lowery (1996) The Population Ecology of Interest Representation: Lobbying Communities in the American States. Ann Arbor: University of Michigan Press.

Grossman, P. (1988) Government and Economic Growth: A Non-Linear Relationship. Public Choice 56, 193-200.

Kiviet, J. F. (1995) On Bias, Inconsistency, and Efficiency of Various Estimators in Dynamic Panel Data Models. Journal of Econometrics 68:1, 53-78.

Knowles, S. and P. D. Owen (1995) Health Capital and Cross-country Variation in Income Per Capita in the Mankiw-Romer-Weil Model. Economics Letters 48:1, 99-106.

Laband, D. N. and J. P. Sophocleus (1988) The Social Cost of Rent-Seeking: First Estimates. Public Choice 58, 269-275.

Leff, N. (1964) Economic Development through Bureaucratic Corruption. American Behavioural Scientist 8:3, 8-14.

Levine, R. and D. Renelt (1992) A Sensitivity Analysis of Cross-country Growth Regressions. American Economic Review 82:4, 942-963.

Mauro, P. (1995) Corruption and Growth. Quarterly Journal of Economics 110:3, 681-712.

Mankiw, N. G., P. M. Romer, and D. N. Weil (1992) A Contribution to the Empirics of Economic Growth. The Quarterly Journal of Economics 107:2, 407-437.

Méon, P. and L. Weill (2010) Is Corruption an Efficient Grease? World Development 38:3, 244-259.

Mendez, F. and F. Sepulveda (2006) Corruption, Growth and Political Regimes: Cross Country Evidence. European Journal of Political Economy 22, 82-98.

Mohtadi, H. and T. Roe (2003) Democracy, Rent Seeking, Public Spending and Growth. Journal of Public Economics 87, 445-466. 
Mork, K. (1993) Living with Lobbying: A Growth Policy Coopted by Lobbyists Can be Better than No Growth Policy at All. Scandinavian Journal of Economics 95, 597-605.

Murphy, K. M., A. Shleifer, and R. W. Vishny (1991) The Allocation of Talent: Implications for Growth. Quarterly Journal of Economics 106:2, 503-530.

Murphy, K. M., A. Shleifer, and R. W. Vishny (1993) Why Is Rent Seeking So Costly to Growth? American Economic Review 83:2, 409-414.

Narayan, P., S. Narayan, and R. Smyth (2011) Does Democracy Facilitate Economic Growth or Does Economic Growth Facilitate Democracy? An Empirical Study of Sub-Saharan Africa. Economic Modelling 28:3, 900910.

Nawaz, S. (2012) The Institutions-Growth Nexus: Evidence from Asian Countries. (Unpublished Paper).

North, D. C. (1990) Institutions, Institutional Change and Economic Performance. Cambridge, MA: Cambridge University Press, New York.

Park, H., A. Philippopoulos, and V. Vassilatos (2005) Choosing the size of the Public Sector Under Rent Seeking from State Coffers. European Journal of Political Economy 21, 830-850.

Peev, E. and D. C. Mueller (2012) Democracy, Economic Freedom and Growth in Transition Economies. Kyklos 65:3, 371-407.

Rama, M. (1993) Rent Seeking and Economic Growth: A Theoretical Model and Some Empirical Evidence. Journal of Development Economic 42, 3550.

Romer, P. M. (1986) Increasing Returns and Long-Run Growth. Journal of Political Economy 94:5, 1002-1037.

Romer, P. M. (1994) The Origins of Endogenous Growth. The Journal of Economic Perspectives 8:1, 3-22.

Sachs, J. D. and A. Warner (1997) Fundamental Sources of Long-run Growth. American Economic Review 87:2, 184-88.

Sajid, A. and A. Cooray (2012) Financial Development, Political Rights, Civil Liberties and Economic Growth: Evidence from South Asia. Economic Modelling 29:3, 974-98.

Scully, G. W. (1991) Rent Seeking in U.S. Government Budgets, 1900-88. Public Choice 70, 99-106.

Spinesi, L. (2009) Rent-seeking Bureaucracies, Inequality, and Growth. Journal of Development Economics 90:2, 244-257.

Svensson, L. (2000) Foreign Aid and Rent Seeking. Journal of International Economics 51, 437-461.

Tullock, G. (1967) The Welfare Costs of Tariffs, Monopolies, and Theft. Western Economic Journal 5, 224-232. 